\title{
Sensitivity of seminal vesicles to androgen stimulation during puberty in mice: effect of treatment duration
}

\author{
T. D. McKinney \\ Division of Allied Health and Life Sciences, University of Texas, \\ San Antonio, Texas 78285 , U.S.A.
}

It has been suggested that sensitivity of the hypothalamic-pituitary unit to feedback inhibition by androgens may decline at the onset of puberty in the rat (Negro-Vilar, Ojeda \& McCann, 1973), and that effects of gonadotrophins on testis weight may be greater before than after puberty (Swerdloff, Jacobs \& Odell, 1972). In rats, the epithelium of the seminal vesicle is most sensitive to androgen stimulation between 40 and 60 days of age (Hooker, 1942), and the sensitivity of the seminal vesicles in neonatally castrated mice to androgens during adulthood is influenced by neonatal androgen treatment (Bronson \& Desjardins, 1969; Bronson, Whitsett \& Hamilton, 1972). The present studies were therefore undertaken to examine the effects of various androgen treatments between weaning and puberty on the growth of seminal vesicles of castrated mice.

The mice used were from a long-established laboratory colony derived from wild animals. Matings in the colony were non-selective, and wild males were introduced occasionally to reduce inbreeding. Males were weaned, castrated and caged singly at 21 days of age in the presence of excess food and water at $25^{\circ} \mathrm{C}$, and with $14 \mathrm{hr}$ light $/ 24 \mathrm{hr}$. All mice were killed by cervical dislocation $24 \mathrm{hr}$ after the last injection. Following fixation of the eviscerated carcass in $10 \%$ neutral buffered formalin for at least $48 \mathrm{hr}$, seminal vesicles were removed, trimmed of adhering tissue and coagulating glands, and weighed to the nearest $0.1 \mathrm{mg}$. Experimental treatments, number of animals per treatment, and results are summarized in Table 1.

Androgen dependency of growth of seminal vesicles is reflected in the consistently reduced weights of the glands in animals in Groups 1-4, while injections of testosterone propionate daily from 21 days of age (Group 5) resulted in a nearly threefold increase above the values for oil-injected controls by 35 days of age. In Group 6 , the seminal vesicle weights were $70 \%$ heavier than those in Group 5 $(P<0.001)$, and five times heavier than in untreated castrates (Group 2). Weight of the seminal vesicles increased by another $59 \%$ by 50 days of age (Group 7 versus Group $6, P<0.001$ ), and reached a maximal sixfold increase compared with values for Group 3 animals.

Table 1. Mean ( \pm S.E.M.) seminal vesicle weights in house mice castrated at 21 days of age, showing the effects of various regimens of s.c. treatment with testosterone propionate (TP) in $0.1 \mathrm{ml}$ sesame oil

\begin{tabular}{clccc}
\hline Group & \multicolumn{1}{c}{ Treatment } & $\begin{array}{c}\text { Age during } \\
\text { treatment } \\
\text { (days) }\end{array}$ & $\begin{array}{c}\text { No. of } \\
\text { animals }\end{array}$ & $\begin{array}{c}\text { Wt of seminal } \\
\text { vesicles } \\
\text { (mg) }\end{array}$ \\
\hline 1 & Sesame oil, $0 \cdot 1 \mathrm{ml} /$ day & $21-35$ & 5 & $2 \cdot 6 \pm 0 \cdot 2$ \\
2 & Sesame oil, $0 \cdot 1 \mathrm{ml} /$ day & $21-40$ & 4 & $2 \cdot 3 \pm 0 \cdot 1$ \\
3 & Sesame oil, $0 \cdot 1 \mathrm{ml} /$ day & $21-50$ & 4 & $2 \cdot 9 \pm 0 \cdot 3$ \\
4 & Sesame oil, $0 \cdot 1 \mathrm{ml} /$ day & $21-60$ & 4 & $3 \cdot 1 \pm 0 \cdot 3$ \\
5 & TP, $2 \mu \mathrm{g} /$ day & $21-35$ & 9 & $6 \cdot 8 \pm 0 \cdot 7$ \\
6 & TP, $2 \mu \mathrm{g} /$ day & $21-40$ & 9 & $11 \cdot 6 \pm 0 \cdot 8$ \\
7 & TP, $2 \mu \mathrm{g} /$ day & $21-50$ & 8 & $17 \cdot 5 \pm 1 \cdot 5$ \\
8 & TP, $2 \mu \mathrm{g} /$ day & $21-60$ & 10 & $6 \cdot 5 \pm 1 \cdot 0$ \\
9 & TP, $2 \mu \mathrm{g} /$ day & $26-40$ & 9 & $8 \cdot 6 \pm 0.9$ \\
10 & TP, $2 \mu \mathrm{g} /$ day & $36-50$ & 9 & $7 \cdot 2 \pm 0 \cdot 6$ \\
11 & TP, $2 \mu \mathrm{g} /$ day & $46-60$ & 18 & $3 \cdot 0 \pm 0 \cdot 3$ \\
12 & TP, $7 \cdot 2 \mu \mathrm{g} /$ day & $35-40$ & 16 & $3 \cdot 9 \pm 0 \cdot 5$ \\
13 & TP, $11 \cdot 2 \mu \mathrm{g} /$ day & $45-50$ & 14 & $3 \cdot 6 \pm 0 \cdot 3$ \\
14 & TP, $15 \cdot 2 \mu \mathrm{g} /$ day & $55-60$ & & 0 \\
\hline
\end{tabular}


In contrast to the effects of daily injections of testosterone propionate from weaning, $2 \mu \mathrm{g}$ daily for the 14 days before 40,50 or 60 days of age (Groups 9, 10 and 11) did not stimulate different amounts of growth of the seminal vesicles. Treatment with $36 \mu \mathrm{g}, 56 \mu \mathrm{g}$ or $76 \mu \mathrm{g}$ testosterone over a 5-day period (Groups 12,13 and 14) did not result in a significant increase in seminal vesicle weight compared with the values for castrated mice (Groups 2, 3 and 4).

The present results demonstrate that exposure to low levels of testosterone propionate from weaning through puberty elicits an increased sensitivity of the seminal vesicles to continued androgen stimulation. That increases in gland weight were dependent upon duration of previous exposure to androgens rather than upon age of the animal and total amount of hormone injected is suggested by the failure of shorter periods of treatment to affect seminal vesicle weight differentially at the various ages, even though the total dosage approached or equalled that given from weaning. Thomas \& Strauss (1965) also suggested that, in the intact mouse, duration of steroid administration may be more important than total amount of hormone injected in stimulating production of seminal vesicle fructose. Moreover, the data support and extend previous reports indicating a priming effect in mice of neonatal androgenization on seminal vesicle sensitivity to androgens during adulthood (Bronson \& Desjardins, 1969; Bronson et al., 1972).

Although androgen-dependency of seminal vesicle function has long been recognized (Burrows, 1945), the hormone-dependent development of these accessory sex glands is poorly understood (Clegg, 1966). In the intact house mouse (McKinney \& Desjardins, 1973) and rat (Hooker, 1942; Resko, Feder \& Goy, 1968), initial growth of seminal vesicles, at least in terms of gland weight, is associated with rising titres of plasma androgens, and growth of the glands essentially parallels circulating levels of androgens before and during puberty. However, factors other than increased levels of plasma androgens may be important in ontogeny of seminal vesicle function. For example, plasma androgen titres decline after puberty, yet weight and fructose concentration of the seminal vesicles remain asymptotic (Hooker, 1942; McKinney \& Desjardins, 1973; Resko et al., 1968).

While the present data provide no insight into the intracellular mechanisms involved, they are consonant with accumulating evidence that the process of puberty is associated with changes in sensitivity of neural and endocrine factors to the circulating gonadal steroids (Negro-Vilar et al., 1973; Swerdloff et al., 1972; McKinney \& Desjardins, 1973).

The study was partly supported by USPHS Grant HD08545.

\section{References}

Bronson, F.H. \& Desjardins, C. (1969) Aggressive behavior and seminal vesicle function in mice: differential sensitivity to androgen given neonatally. Endocrinology 85, 971-974.

Bronson, F.H., Whitsett, J.M. \& Hamilton, T.H. (1972) Responsiveness of accessory glands of adult mice to testosterone: priming with neonatal injections. Endocrinology 90, 10-16.

BURrows, H. (1945) Biological Actions of Sex Hormones. 1st edn. Cambridge University Press.

ClegG, E.J. (1966) Pubertal growth in the Leydig cells and accessory reproductive organs of the rat. $J$. Anat. 100, 369-379.

HoOKer, C.W. (1942) Pubertal increase in responsiveness to androgen in the male rat. Endocrinology 30, 77-84.

MCKinney, T.D. \& Desjardins, C. (1973) Postnatal development of the testis, fighting behavior, and fertility in house mice. Biol. Reprod. 9, 279-294.

Negro-Vilar, A., Ojeda, S.R. \& McCanN, S.M. (1973) Evidence for changes in sensitivity to testosterone negative feedback on gonadotrophin release during sexual development in the male rat. Endocrinology 93, 729-735.

RESKo, J.A., Feder, H.H. \& GoY, R.W. (1968) Androgen concentrations in plasma and testis of developing rats. J. Endocr. 40, 485-491.

SWERdLOFF, R.S., JACOBS, H.S. \& Odell, W.D. (1972) Hypothalamic-pituitary-gonadal interrelationships in the rat during sexual maturation. In Gonadotrophins, pp. 546-561. Eds B. B. Saxena, C. G. Beling \& H. M. Gandy. Wiley-Interscience, New York.

Thomas, J.A. \& Strauss, A.J., JR (1965) The effects of steroids on mouse sex accessory fructose levels. Acta endocr., Copenh. 48, 619-629. 